\title{
Feminist Political Discourses in the Digital Era: A new materialist discursive analysis of the \#BringBackOurGirls cyber-campaign
}

\author{
Beatriz Revelles-Benavente \\ UNIVERSIDAD DE GRANADA \\ beatrizrevelles/augr.es \\ ORCID: 0000-0003-1334-6257
}

Received: 01/04/2019

Accepted: 29/01/2020

\begin{abstract}
Increasing use of cyber-campaigns is being made by social movements and political groups. Nevertheless, this popularity is often accompanied by undesirable consequences for social movements such as the violence denounced by contemporary feminism. Thus, some digital mobilisations create a rift between the physical and digital worlds - something that often gives rise to homogenisation of socio-cultural categories such as gender, race, and age. In this paper, we analyse the \#BringBackOurGirls campaign, which sprang to life five years ago. Its path reveals the success of these cyber-campaigns in the field of contemporary feminism. Feminist Critical Discourse Analysis (FCDA) is used to take a feminist genealogical approach to new materialisms. In doing so, it examines the temporal and spatial trajectory of the campaign to reshape affirmative feminist politics. These politics involve reconfiguring pre-established notions such as 'girl', 'agency', and 'otherness' to provide social movements with the capacity to respond. We therefore undertake an ethnographic examination of the hashtag (Bonilla \& Rosa, 2015) to compare the beginning of the campaign with the situation now. We draw on these results to localise the shift from the local scale to the global one, in which structural powers, individual agency, and 'glocal' [local-global] and feminist affirmation policies become diluted.
\end{abstract}

Keywords: FCDA, hashtag ethnography, \#BringBackOurGirls, new materialist kinds of Feminism, new kinds of materialism, agency.

Corresponding author: Beatriz Revelles Benavente. Campus de la Cartuja, Universidad de Granada, Calle del Prof. Clavera, s/n, 18011 Granada (Spain).

Suggested citation: Revelles-Benavente, B. (2020). Feminist Political Discourses in the Digital Era: A new materialist discursive analysis of the \#BringBackOurGirls cyber-campaign. Debats. Journal on Culture, Power and Society, 5, 245-259. D0I: http://doi. org/10.28939/iam.debats-en.2020-14 
On the $14^{\text {th }}$ of April 2014, 276 girls were abducted by the terrorist group ${ }^{1}$ Boko Haram when they were attending a Catholic school in the Chibok region of Nigeria. Of these 276, today ${ }^{2}$ no fewer than 112 girls are held by the Boko Haram. Despite the gravity of the kidnappings and the insurgency that gave rise to it, it was not until late April or early May 2014 that the kidnappings began to have a global impact - thanks to the \#BringBackOurGirls cyber-campaign. It was begun by a lawyer by the name of Ibrahim Abdullahi. He tweeted the words uttered by ObyEzekwesili on the $23^{\text {rd }}$ of April during the inaugural speech of Nigeria's APC Party (All Progressive Congress) ${ }^{3}$ at UNESCO (Maxfield, 2016). The number of hashtag posts has swung wildly over the last five years, while media interest has waned greatly. The way the campaign has unfolded makes some scholars and activists wonder whether the whole thing is little more than an exercse in 'social clicking' (Maxfield, 2016). Taking this perspective, many users are happy to just click on a button yet this gesture may stop them taking political action outside the purely digital sphere. Another criticism levelled at campaigns like this is that they can lead to 'post-colonial' practices. Other critics see post-colonial practices in the way countries such as The United States pursue a political strategy that de-legitimises the Nigerian Government

1 The researchers are aware of the onto-epistemological debate in both academic and public policy circles on the difference between terrorist groups and violent extremism. However, as this subject will be covered extensively in other papers in this special issue of Debats, the authors have opted for the term "terrorist group" for semantic reasons. We consider that violence - be it physical or mental - is always extreme. That said, Boko Haram is a group whose whole policy is based on terror (Massumi, 2005) on both a local and global scale. Its activities have directly affected a group of girls who previously had nothing to do with either Boko Haram or with violent conflict (political, sociological, economic, or religious) in Nigeria.

2 That is, the $27^{\text {th }}$ of January 2020.

3 The full speech can be accessed at the following links: https://www.youtube.com/watch? $v=e P e M k C A-5 n U$ (part 1) and at https://www.youtube.com/watch?v=KUPBA6MZV2I (part 2). Last access: 09/01/2019. currently in power (Respondent ${ }^{4}$ Chiluwa and Ifukor, 2015).

However, one should first note certain aspects that tend to be overlooked by these critics. One is "the context in which the campaign began and the assumption that its concepts of race and nation stayed constant throughout" (Maxfield, 2016: 886). The trajectory of these cyber-campaigns and their impact on the ground are matters of special interest in our paper. We also analyse the \#BringBackOurGirls campaign to discover the setting that spawned the campaign. In doing so, we take an intersectional (or rather intra-sectional) approach to find a common thread running through the digital ethnography. To this end, the paper focuses not only on the concepts of 'nation' and 'race' but also on 'gender' and 'age'. That is because we consider them vital for understanding this particular campaign.

The methodological approach used in this paper is that of digital ethnography (Pink et al., 2016), and more specifically Bonilla and Rosa (2015: 5) term this an "ethnography of the hashtag". The use of said ethnography lets us analyse the diverse discourses on a given subject since the hashtag itself categorises and indexes specific content (Xu and Zhou, 2020). It is thus easier to establish a relationship between frequent content on a given digital platform and discursive patterns than would otherwise be the case with a traditional critique bereft of such digital tools. As a case study, Bonilla and Rosa (2015) cite the case of Michael Brown, a defenceless black boy shot by a policeman in the city of Ferguson, Missouri in 2004. The shooting triggered a wave of protests and social movements in the US whose impact was so great that even today some public figures still link the case with the one covered in our paper despite the differences

4 The qualitative methodology used in this paper includes: semi-structured interviews of local experts such as journalists, lawyers, and social activists with experience of this conflict. These interviews lasted an hour and were recorded after signing an informed consent on the use of the data. We use 'informant' throughout to maintain anonymity. There are five semi-structured interviews in all but this paper will use the data provided by a journalist of Nigerian origin. 
and time between the two (Maxfield, 2016). Here, one should note that that both of these cyber-campaigns show that "the rising use and availability of these technologies provides new documentation tools", and greater scope for discourses countering those found in the media (Bonilla and Rosa, 2015: 5).

Sassen (2017: 173) states that "the new ICTs [...] invite a new conceptualisation of the local sphere that can be adapted to cases that depart from the dominant patterns". For this reason, feminist movements need to design cybera-ctivist campaigns that "seek crossborder political practice, even when it comes to actors confined to the local sphere" (Sassen, 2017: 173). In explaining how the new ICTs work, Sassen points to the origin of certain NGOs that are active today, adding: "The types of political practices that are being debated are not ones charting a cosmopolitan path to the global sphere. Such practices only become truly global once local ones have spread far and wide. Thus in order to grasp how the \#BringBackOurGirls campaign unfolded, we need to go back to the beginning and find out which practices spread. Thus the methodological point of departure for a given hashtag campaign is to see how it has spread and changed over time (5 years in the case of the \#BringBackOurGirls one). That is why our paper used a qualitative sample, spanning from the month in which the hashtag was opened (May 2014) to activity in the month in which the first version of this paper was written (August 2019). We are therefore faced with an asynchronous ethnography for analysing discursive patterns since "platforms such as Twitter fuel information exchange and vibrant debates fostering deep criticism of power relations. Such debates are key for spreading public knowledge of discourses urging resistance and that were formerly confined to fringe groups" (Xu and Zhou, 2020: 88).

This comparison should reveal which practices are spreading most and what impact they may have. It will help us grasp how a cyber-campaign starts and what outcomes it yields (in this case, after five years). These practices will be examined within the ethicalontoepistemological framework of new materialisms (Van der Tuin, 2015; Colman, 2020). This will help pin down key concepts, revealing how 'otherness', 'agency', and 'responsibility' work in this particular case. These categories drive the discourse and the ethnographic analysis, which we develop later on Understanding their digital and analogue evolution will help us identify how feminist political actions can lead to local responses to structural problems.

\section{CONFLICT GENEALOGY: CONTEXTUALISATION OF THE ORIGIN OF THE \#BRINGBACKOURGIRLS HASHTAG CAMPAIGN}

To grasp how the digital cyber campaign evolved, one needs to chart the chronology of the conflict, taking into account two strands (1) the post-colonial history of Nigeria; (2) the events surrounding the kidnappings. We shall first briefly look at Nigeria's post-independence history to shed light on the present state of affairs (Figure 1).

The research team's figure for this special issue and paper sheds light on Nigeria's recent history and the succession of democratic presidents, as well as the link with local politics, which had to grapple with the armed conflict that began in 1995. However, it was not until 2009, with the death of Boko Haram's main leader, Yusuf Shekau, that tension between the government and the terrorist group began to rise.

The figure 2 shows the 'genealogy' of the kidnappings.

The figure gives a kind of 'genealogy' of the kidnappings, and what we identified as a key moment in the unfolding events - namely the 2015 propaganda video showing the girls in captivity. The video went 'viral' and was picked up by the media which in the process greatly spread the terrorist group's propaganda. This shows the influence social networks and global media wield in reporting on local event - an issue that will be explored in other articles in this special edition of Debats.

Both figures show how the kidnapping happened between two key moments in Nigeria's recent history, 
Figure 1 Post-Colonial Nigeria

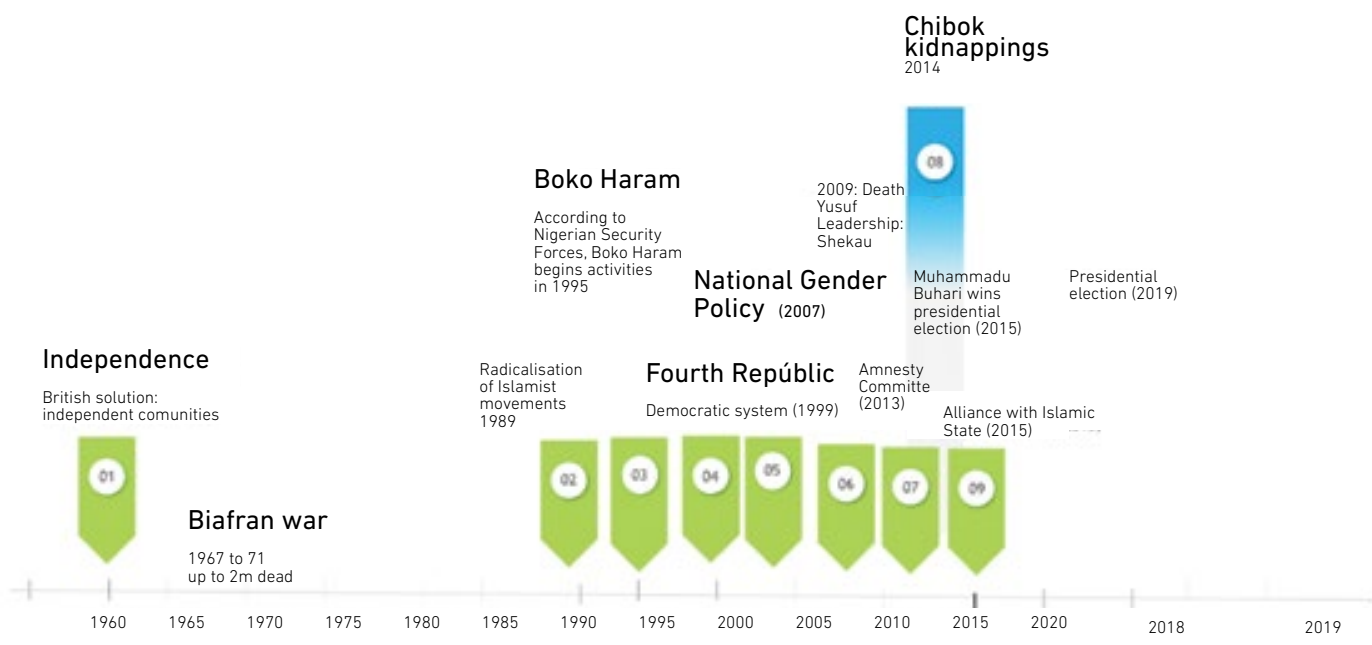

Figure 2 Kidnapping genealogy

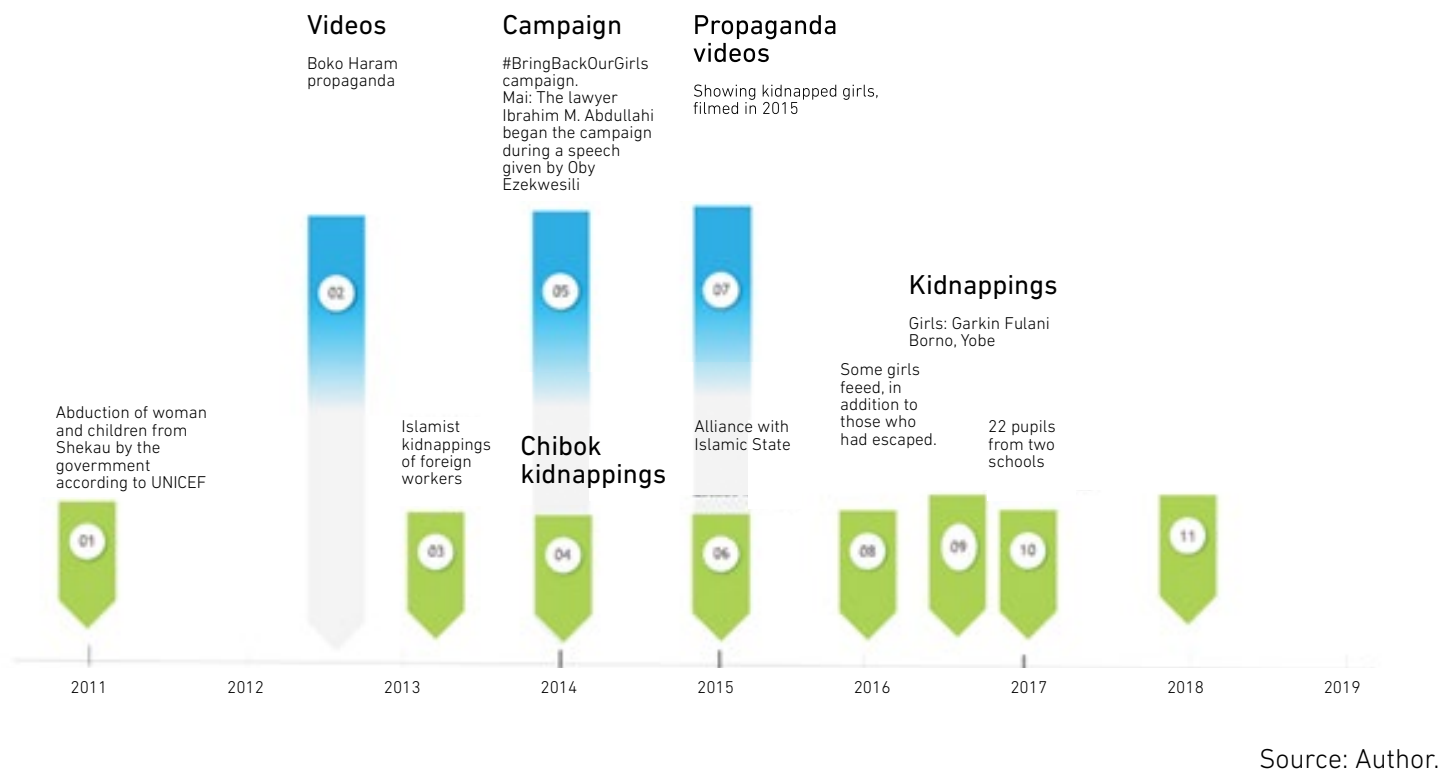


namely after the Amnesty International Committee (2013) reporting on the situation in the country (until then, an issue that was largely a domestic matter) but a year before the 2015 Presidential election. In September 2014, Oby Ezekwesili gave an interview in The United States in which she spoke of the benefits of the cyber-campaign itself and of the continuity she felt was needed if it was to have a real impact (Channels Televisions, 2014a and 2014b). In her view, this cybermarketing brought the issue into the "bedrooms" 5 of many people who saw it as something close to their own hearts. This helped win global support and reach for the campaign (Minute 9 of the video). Likewise, she also argued that such cyber-campaigns cannot work alone but rather need to be accompanied by physical deeds. For Ezekwesili (Ajoke's Diary, 2014, Minute 10), the physical deed required was none other than the girls' rescue - something she saw ${ }^{6}$ as the "responsibility" of Nigeria's Federal Government. This was the self-same government that years later (2019) chose not to internationally publicise the next elections because it feared Western countries would seize the opportunity to meddle in the country's local politics (Informant).

According to April Mandrona (2016: 3), we need "to produce new imaginaries and understandings of the ethical being, rights, otherness, power, agency and responsibility" in order to think coherently about the situation of girls around the world. The truth is that some of these concepts are self-referential and lack a coherent or transversal definition that is in keeping with the society or the institutional/media/academic discourse they are used for. On the one hand, the

5 The words between quotation marks are those spoken by the former Nigerian Education Minister. Words always have a symbolic and material meaning and their action within a political discourse and the way they are used - even in an interview - is not accidental. The full interview can be found at https://www.youtube.com/watch?v=cRTVEkBnoCk. Last access: 09/01/2019.

6 Here one should note the verb tense of the actions, since during the period spanning from the outbreak of the conflict to the present, Ezekwesili has gone from being Minister of Education to being a Presidential candidate. At the time of this interview, she held neither of these positions but was an advisor to the Nigerian Government. special features of each socio-cultural community shape cause and effect. On the other hand, failure to adopt a conceptually broader methodology capable of driving affirmative action and intervention (a concept that will be developed later) is a stumbling block to 'social transformation'. Colman (2014) prefers the term 'social change', to differentiate it from a more Western notion of progress leading to more specific sociological transformation.

Before delving deeper into the paper's theme, we should like to start from what Donna Haraway (1988) calls "situated knowledge", which can be considered as knowledge that starts from a specific relational experience that is diffracted by or interacts with a more global setting. Here, we proffer a provisional definition of three concepts that we consider key to grasping the complexity of the project that we have embarked upon. These concepts are: Otherness, Agency, and Responsibility. Carrying out an ethnographic analysis of the hashtag requires epistemological-empirical mobilisation enshrining these three concepts given that its ontology is defined as "the creation of discursive spaces for individuals who participate in cultural creations of meanings arising from the development of various themes" (Xu and Zhou, 2020: 89). Thus we need to identify which analytical categories mobilise the issue covered in this paper.

As Ezekwesili's words show, it is important to identify who should be held responsible for rescuing the girls. This type of discourse already identifies three levels of analysis that complicate the socio-cultural conflict but that also help begin the analysis with someone who wields political influence in the conflict. Rescuing the girls involves pondering:

1 Who is the 'other'? Is it the government of Nigeria? Is it the terrorist group? Is it the people in their "bedrooms" (sic)? Is it the people behind the click?

2 Who has agency to promote this rescue? This factor is closely linked to the concepts of 'otherness' and 'responsibility', which we will define later. This is so because agency is 
shared by the nature of the cyber campaign and the unique physical actions identified by Ezekwesili.

3 Who is responsible and in what sense is this person/body able to 'rescue' the girls? What does the notion of 'rescue' imply for those girls who are still unaccounted for? At the same time, these concepts underpin the approaches used to reach our conclusions.

However, all these categories are based on self-referential concepts that cannot easily be applied outside the local context of the conflict. An intersectional approach (Cho, Crenshaw \& McCall, 2013) reveals the need to incorporate various dimensions so that one can start from a common base: gender, age, religion, sexuality, ethnicity, origin, among many other things - as we shall see later. Nevertheless, grasping what 'girl' means in Nigeria requires a departure from Western ideas about girlhood given that there are marked differences. Likewise, thinking about the meaning of 'girl' leads us on to the concept of 'otherness' and 'agency' in this case, since the campaign demands that we "bring the girls back." "Others" have to acknowledge the abducted girls' place of origin and rescue them from thraldom in the terrorist camps.

One might argue that the cyber-campaign was focused solely on freeing the girls but over time it became a representationalist media claim. We thus propose the new materialist concept of "intra-sectionality" (Geerts and Van der Tuin, 2013). Here, 'agency' is understood within the scope of the digital relationship covered by our case study, and 'responsibility' as 'the ability to respond' (Haraway cited by Revelles Benavente and González, 2017) to the present political framing of the conflict. The first section of the paper covers theory. The second section sets out our research methodology. The third uses hashtag ethnography (Rosa and Bonilla, 2015) to delve into the case and mainly focuses on materialdiscursive analysis guided by the aforementioned three empirical-methodological concepts. The paper ends with constructive proposals for affirmative intervention to boost the ability to respond but that do not 'colonise' the \#BringBackOurGirls case. Rosi Braidotti's affirmative policy (2015) is a post-human strategy based on the quest for forums fostering active but non-destructive resistance. Such resistance forges empowering spaces rather than giving agency to people and other actors in a given conflict. It is an affirmative policy that seeks social and ethical transformation based on relationships, not on hierarchical disruption that merely leads to new hierarchical anthologies.

\section{INTRASECTIONALITY: THINKING THROUGH THE NOTION OF 'GIRL' IN THE SOCIAL MEDIA}

In 1990 Rosi Braidotti explained 'difference' as a multi-faceted thing, not as an 'either/or' choice (as in 'woman' as 'not man'). There are various levels of difference - men versus women, among women (breaking with the univocal notion of 'woman' in within feminist theory and for the political movement in general). However, as Mandrona (2016) states, girls are different from women, so one more level could be added to that proposed by Braidotti to grasp the ontological differences between the two. According to Chiluwa and Ifukor (2015), the girls who were abducted from the Chibok school were aged between 14 and 18. In the context of Nigerian culture, that means that some of them were already considered to be potential mothers. Making these women seem like children (from a Western perspective, in which they would still be considered girls) gives rise to a counterdiscourse ('these girls must be rescued) that attacks the Nigerian government and the terrorist group alike. However, we cannot understand the viral discourse of the campaign from this Western standpoint since we would be victimising and 'post-colonising' the girls who are the centre of the media campaign on three different levels:

1 For feminists and NGOs promoting the 'girls' liberation.

2 For the Nigerian government (which needs the girls to regain the legitimacy it has lost in the eyes of the world). 
3 For the terrorist group, which uses the 'girls' as bargaining chips and to keep the organisation in the media spotlight?

Contemporary feminist theory relies on the concept of intersectionality to analyse and explain these differences. However, this concept as really just a tool for delineating difference. Contemporary theory tries to go beyond this. According to Cho, Crenshaw and McCall (2013: 788), intersectionality is "an analytical tool that captures and relates to contextual power dynamics [...] it is a nodal point that brings together investigations with open ends of the following dynamics (considered conflictive and overlapping): race, gender, class, sexuality, nationality and other inequalities". Thus, they define it as a starting point for capturing the complex social dynamics in which sundry oppression factors interfere in a given sociological development.

Additionally, the intersectional approach also allows one to begin with empirical work as a first step to theorising about the data (Cho, Crenshaw and McCall, 2013: 792). Bearing in mind the 'suspension of the present' implied by the analysis of social networks (Coleman, 2018), it hard to reconcile starting from a previous theory to frame the results with the need not to 'colonise' them. However, as we have shown through discursive genealogy, the linguistic representation of the campaign is univocal - a criticism of the intersectional perspective that is fairly common in contemporary feminist theory. For example, Evelien Geerts and Iris Van der Tuin argue that this approach can fall into representationalist traps (2013) in which the intersection of certain social categories is presented as an active component of the research, while the participating subjects become passive components.

This digital campaign might be seen as a clear example of the consequences of this intersectional representationalist reading. The three media levels focusing on the notion of 'girl' to develop the campaign fall precisely into this reading and foster highly specific political practices in the cyber-campaign, as we shall see later. Part of the project that we present in this special issue consists of the development of semistructured interviews with local agents and experts on the subject. One of our informants told us that digital campaigns such as \#BringBackOurGirls had turned the Chibok girls into a symbol and 'bargaining chip' for the terrorist group in its dealings with the international press. This gave the terrorists even less reason to release the girls, most of whom remain in captivity to this day. We therefore consider the scope for applying active intersectionality principles in both our research methodology for this project and for part of this paper. Here, one should note the interrelationship of different identities defining a given group and their link to the node (or platform) upon which Crenshaw's intersectional approach is based. This node would be the digital campaign itself and a notion of social networks as a 'suspension of the present'. In addition, our approach also moves away from the 'subjugated knowledge' concept espoused by Sandra Harding (1986). That is because we seek to activate 'situated knowledge' (Haraway, 1988) as the starting point for the girls' relational agency rather than just considering them as victims who must be shielded by 'White Feminists' .

Thus we try to explain the campaign's corporal and affective expressions from the standpoint of relationships - physical and digital — rather than from the personification or objectification of certain pictures. Maxfield (2016: 885) warns us that "digital expressions were part of a larger reality and were therefore involved in their own stories and systems of power". Thus continues Maxfield (2016: 885) — the genealogy of the conflict and its presentation in the media sometimes grant agency to figures from The Global North, such as the film director Ramaa Moseley. The upshot is that Nigerians enter our imaginary as "poster girls" rather than as individuals relating their experiences in their own words (Maxfield, 2016: 891). This intrasectional approach analyses: (1) specific moments; (2) the scope for altering the concepts described earlier; (3) the lessons for affirmative intervention in the design and dissemination of feminist cyber-campaigns. We say 'affirmative intervention' because instead of focusing on the potential pitfalls of such a campaign for feminism (see Maxfield, 2016, for example), we analyse relational moments that can yield answers (or exhibit 'responsibility', as Haraway would put it). 


\section{TWITTER: AN EMPOWERING SPACE FOR AFFIRMATIVE POLICIES?}

According to Sassen (2017: 173), "The digital media are key for activists rooted in specific physical spaces, and focusing on local issues that link to similar groups in other parts of the world." One of the main functions of the tweets that $\mathrm{Xu}$ and $\mathrm{Zhou}$ (2020: 89) identify is the ideological demarcation of an individual person within a discursive space (which, we add, is a collective one). Thus, we can verify how physical spaces and discursive spaces converge in certain patterns, yielding local and global explanations of certain contemporary phenomena. In this respect, Twitter catalyses the convergence of diverse identities with different geo-political positions. When it comes to the methodological approach to this social network, quantitative approaches based on the use of technological software are commonly used (for example, Xu and Zhou, 2020; Rosa and Bonilla, 2015). This paper stresses two specific periods in the Twitter campaign. It does so to establish representationalist discursive patterns exhibiting a Western, post-colonial vision of the empirical and epistemological concepts noted above. Here, we not only analyse the most recurrent tweets during the two periods but also delve into the images produced. Visual media accompanying the discourse is a key feature of the Twitter platform. Images play a major role in shaping how we see and feel about a given subject (Whitty et al., 2018). One should also note that pictures make a faster impact than text and may well be subject to a wider range of interpretations.

In contextualising the conflict, we have taken up Mandrona's (2016) suggestion of changing the imaginary so as to tackle the host of patriarchal relationships arising from the mix of social networks, terrorism, and the girls. This paper delves into the campaign to come up with new imaginaries precisely because it "changed the world's collective perception, swiftly drumming up support for the cause and putting the issues before a worldwide audience" (Njoroge, 2016: 312). It sprang from the efforts of Nigerian parents and activists who felt the nation's government was shirking its duty (Njoroge, 2016: 312). It reveals that the campaign was born in the local sphere, and from the relational agency of a group of people united by emotional ties (mostly forged through family and gender). When the campaign made the leap to the global scale, local agency vanished. This in turn led to the captive girls becoming: (1) a bargaining chip for the terrorists in their haggling with the Nigerian government; (2) a propaganda tool for publicising the terrorists' cause in the world media. Two key factors were highlighted by international actors: (a) the Nigerian government's inability to manage its own crises (Njoroge, 2016: 321); (b) the 'need' for postcolonialist intervention by other countries (such as The United States) - something that completely delocalised the problem. Once an issue had been delocalised, the spotlight fell on media language on and treatment of what was at stake. This is highly undesirable because it makes one lose sight of women's agency. That is why a relational approach is preferable because it is more likely to highlight individual experience and to include the voice of the local women involved in the campaign.

Facebook and Twitter - together with Instagram are fairly interconnected social networks, since the hashtag (\#) allows simultaneous publishing of posts on Facebook and Twitter (even though the latter has a 140-character limit). Njoroge (2016) carried out a rigorous discursive analysis of the origins of the cyber-campaign, focusing more on Facebook. This lets us identify the four thematic points that she considers most important at the outset: "Education for girls; denunciation of human trafficking; religious oppression; women-power" (Njorge, 2016: 320). This theming seeks to identify a feminist discourse in the cyber-campaign. However, the author also notes major hurdles, such as the need to empower girls by inculcating critical thinking. This is hard to say the least because girls do not receive a Western education in Northern Nigeria but rather one that is specific to a region that is far from both the national Capital and the more 'developed' South (according to Western criteria). Rather than trying to empower the girls who are victims of the conflict, one would need to find agency spaces - physical, political and symbolic — to 
give girls in Northern Nigeria the chance to respond to the daily challenges facing them. The cyber-campaign must be accompanied by an analysis of the 'suspended present', seeing it as the relationship between the girls past, present and possible future, and which ties in with the affirmative action taken for them.

\section{THE ANALYSIS OF THE CONFLICT: WHO DO WE BRING BACK?}

The official Twitter account of the \#BringBackOurGirls campaign is the empirical focus of this paper. Instead of undertaking a quantitative analysis, we opted for a qualitative one covering two specific moments in the hashtag's history. These moments highlight the campaign's dynamism and varying intensity. One might say that the hashtag is a kind of avatar spurring on the protest movement to rescue the abducted girls. In September 2019, the account had a fixed tweet, which was the first one to appear on the News Wall every time a user entered the official site. It was dated the $14^{\text {th }}$ of April 2019, marking the fifth anniversary of the Chibok kidnappings. It read as follows:

It is now 5 years since the abduction of 276 \#ChibokGirls from school. For \# 5 YearsTooLong, 112 \#ChibokGirls have remained in captivity. This tragedy is the \#ShameOfANation. Our demand today is the same as it was 5 years ago \#BringBackOurGirls now and alive. ${ }^{7}$

7 In the same way that Yarimar Bonilla and Jonathan Rosa (2015) do in their article (see Footnote 1), this paper includes posts and tweets from the official \#BringBackOurGirls Twitter account. Due to Data Protection laws, the information is anonymised, hiding users' names. We will use the real names only where they have gone viral or are reproduced by the media or public figures. As these authors explain, tweets are sometimes deleted but that does not preclude them from contributing to scientific knowledge. They also refer to the nature of this data, which is sometimes used in an ethically questionable way by corporations such as Facebook or Twitter for commercial purposes. This paper and project are wholly non-commercial, their sole purpose being to contribute knowledge for social ends. https://twitter com/bbog_nigeria?lang=es. Last access: 09/01/2019.
This short tweet tells us that half a decade has gone by since the kidnappings, of the campaign's origin and how almost half (112 out of 276 ) of the abducted girls are still in captivity - "the shame of a nation". The collection of tweets may disappear depending on the scope (Rosa and Bonilla, 2015) - the official Twitter account has over 3,400 followers. This makes tracing the campaigns beginning and gathering all the tweets that have been published a hopeless task. Put baldly, an ethnography of the hashtag showing the first steps in campaign would simply not be viable.

However, there is a second option for marking the cyber-campaign's ontology: harnessing institutional discourses (academic, media, literary) to draw parallels between the impact of the start of the campaign and the campaign today. To this end, we drew up a Feminist Critical Discourse Analysis (FCDA) (Lazaar, 2007) to examine all the tweets during the last month of data collection (August 2019). The FCDA is a qualitative technique that lets one analyse discourses (visual, linguistic, contextual, and so on) taking gender as a transverse axis framing the hierarchies of power that such discourses hide. Being able to contrast the genealogy of the discourse (analogue and digital) with the current state of affairs reveals how the campaign unfolded and came up with an effective plan to use social networks to foster social activism.

In the next section, we will carry out a qualitative analysis to identify the origin of the movement that Oby Ezekwesili talked of earlier. It is contextualised by the genealogy of the conflict itself. To address this 'suspension of the present', we need to insert an FCDA of the tweet that seems anchored, since it establishes the origin of the conflict within the cyber campaign, and linked activity on the platform during the last month. There were thirty-nine tweets from two highly specific public profiles. As a sample of the original tweets, we will take one from each profile to identify the theoretical and methodological starting point that the Twitter account follows today, five years after the outbreak of the conflict. 


\section{THE CONFLICT TODAY: WHO ARE WE BRINGING BACK?}

Following the FCDA technique, we need to adopt gender as the backbone of our analysis, which in our case is clearly demarcated by the symbolic/linguistic label of 'girls'. We contend that the campaign's goal is no longer the initial goal of 'rescue', which we identified in the introduction to this paper. Five long years have passed since the kidnapping took place and there are still victims who remain unaccounted for. Yet these will surely no longer be girls. Not only has enough time passed by to make them adults by Western reckoning (18 years old) but they have also undergone various affective experiences that greatly distance them from the moment of the kidnapping.

If we take the last 39 re-tweets in this account during August 2019 as our sample, we can say that activity lay between medium and high, with an average of over one tweet a day. We can also say that most of the tweets come from two people of very different origins and interests: Rosa Muñiz and Frederica Wilson. If we think about the origin of the conflict and the large number of personalities who joined at the beginning, we can see several familiar faces. As Sassen pointed out at the beginning of this paper, cyber campaigns originate through local actions and become global due to the proliferation of certain deeds. However, this proliferation during the campaign has been strongly marked by the individualisation of the conflict, that is, by the support of recognised public figures from the Global North for the campaign. However, "Having people such as Michelle Obama or David Cameron holding up a slogan and looking fretful does not solve the problem."We, the people, use a hashtag because we do not have the power that these leaders have. I want influential people to act and not just update their status" (Chiluwa and Ifukor, 2015: 285).

Frederica Wilson, a Congresswoman for the Democratic Party in California, uses this conflict and sometimes compares it to the \#BlackLivesMatter movement. However, we cannot forget that the religious, geographical and gender differences (that is, intersectional differences) between these two cases makes it well-nigh impossible to furnish an exhaustive, unifying analysis of both conflicts. Frederica Wilson is a woman of African descent and belongs to the political class of the country's first half-African President.

US political representatives of African descent, headed by the country's first half-African President (born to a mother of European descent and an African father). She and her co-religionaries need a political cause that does not identify with the focus of the conflict but that is grist to the mill of American politics. The situations are completely different but the media representation of both conflicts is very similar. Using this campaign against what she calls "a humanitarian crisis" allows her to position herself within left-wing values that do not compromise the politics of her country. This means that one can update one's status without having to commit to the cause. It is an example of the much-criticised slacktivism and an intersectional representationalist approach on the part of the media and of the way these social networks work.

On the other hand, the most active figure of \#BringBackOurGirls is Rosa Muñiz, who publishes almost daily posts on how many days have passed since the girls were abducted. Muñiz is not someone who holds any power but rather a person who has been doggedly following the same discourse for the last five years. She represents the group of girls who are currently aged between 15 and 23, reproducing the 'suspension of the present' caused by social networks (Coleman, 2018).

If look at the network's present activity in the light of the theories framing this paper, we find a representationalist intersectionality within the Western concept of 'the girls', and a clear-cut case of slacktivism. One can therefore say that the present cyber-campaign is unlikely to end the conflict. Social networks are dissemination tools that catalyse certain information, as we have already seen. However, that information needs to foster a relational response if one to change the facts on the ground. 
Figure 3 Screenshot of the official account of the $25^{\text {th }}$ of August 2019

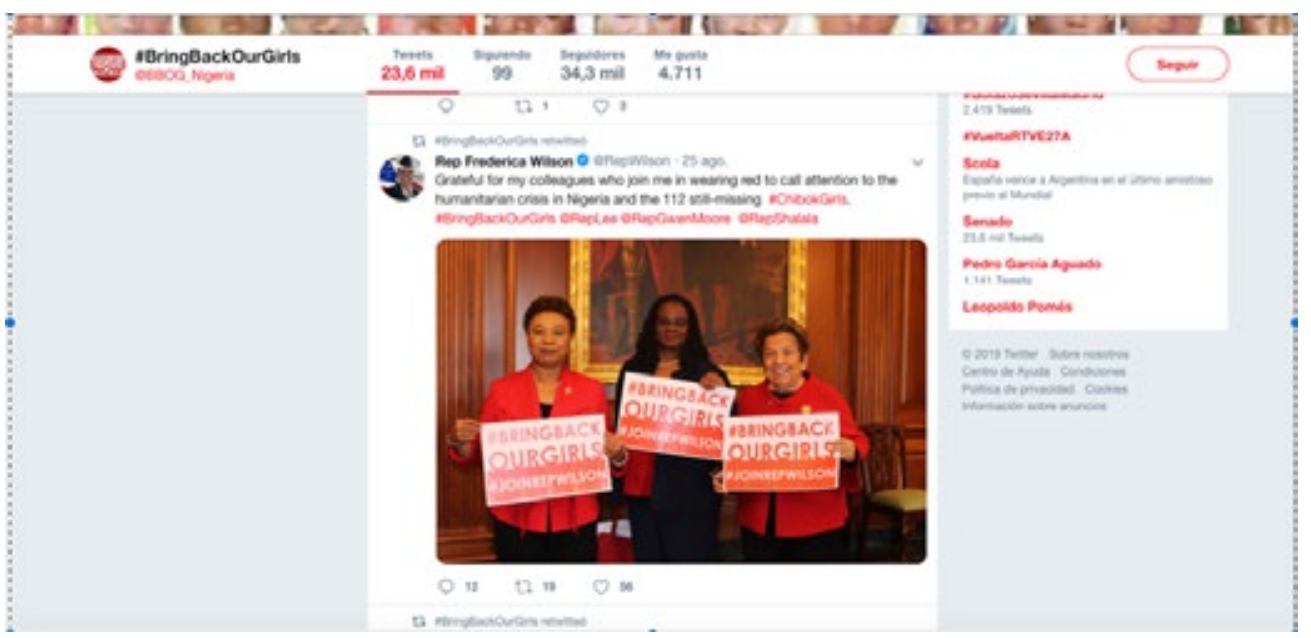

\section{DEVELOPING AFFIRMATIVE FEMINIST POLICIES}

Bearing in mind the sheer complexity of the phenomenon described here, how can one draw up cyber-campaigns that are feminist but that steer clear of Neo-Liberal, Post-Colonial, or even terrorist networks? Isolating the structure of social networks is no easy task given the moment that one's tweet goes viral, one runs the risk of strenghening one's adversary. As Sassen (2017: 177) puts it, "The results are not unidirectional and homogeneous but rather are mixed, contradict one another, and create new elements".

Thus, we propose an onto-epistemological, methodological, and political framework for our approaches. The reason is to better deal with complexity from multiple standpoints rather than simply in terms of cause and effect. The main strands supporting our study are Western Feminism, the pigeon-holing of the victims as 'girls', and politics as an arid exercise in dualism. We not only need feminism as a platform in planning these campaigns but also to ensure a situated 'glocal' [global-local] feminism capable of tackling the structural problems we face. Njoroge (2016) warns us that Western-inspired post-feminism sometimes causes gender issues to be overlooked because they have have supposedly already been 'solved'. These false 'victories' foster an illusory Neo-Liberal feminism in which women can already do whatever they want. Obviously, such feminism is not only a mirage in The East and The South but also in The Global North and in The West. This feminism is born from the dualistic logic that preaches on the norm and by so doing, only reinforces it - something that Butler presciently warned of in the 1990s in Gender Trouble.

The same goes for the concept of empowerment something that Njoroge (2016) wonders about. We consider that this notion has at least two important consequences. The first is the oppositional dualist logic that urges us to search for a feminist who can empower a woman or girl (as already defined by the post-colonial feminism of Spivak or Mohanty, 1988). The second is that it structurally puts women or girls in the role of victims or of executioners. This raises a problem that is basically of a patriarchal nature: the girls cannot get an education and are turned into bargaining chips at both the international and local levels. 
Figure 4 Screenshot of the official account of the $27^{\text {th }}$ of August 2019

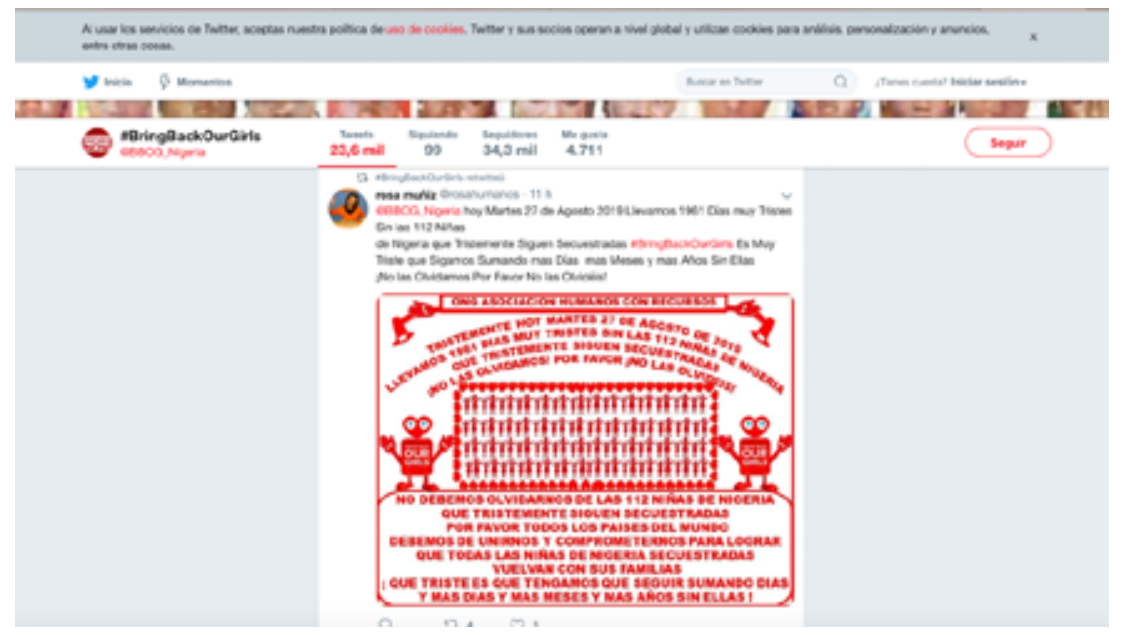

Another element is the conceptualisation of 'girl' and the need to approach this within the intrasectional framework mentioned above. Here, one needs to place these women in their geographic and religious context. There are certain laws that are different in North-Eastern Nigeria. One is that men may indulge in polygamy. Another is that women cannot own land. However, women find other means of financial support in the home (International Crisis Group, 2016). In addition, a report by the International Crisis Group notes that while women's bodies are a battleground in international conflicts, religion, and war, NorthEastern Nigeria has refused to set 18 as the minimum legal age at which women can marry (International Crisis Group, 2016: 3).

Thus, the Nigerian concept of a girl is far removed from ours in The West. Given that the kidnapped 'girls' were aged between 14 and 18 when the abductions took place and that five years have gone by since then, all of the victims are now women. Harping on the 'girls' theme makes for a childish discourse on social networks - something rendered even more absurd by the fact that the conflict has escalated well beyond the initial kidnappings in 2014 . These 'girls' are now women who have adapted to the changes since they were kidnapped. Their situation therefore must be analysed using a different approach. Longrunning feminist cyber-campaigns cannot follow a representational line forever but rather need to be changed as circumstances alter. Painting the conflict in childish terms only strengthens the patriarchal structures found in this part of Nigeria, harming the feminist cause.

This paper proposes feminism that: (1) is based on the affirmative policy strategies set out by Braidotti (2015); (2) identifies the genealogy of the conflict by pursuing an agency relationship that draws on both past and present. These affirmative policies are the starting point for a relationship in which women are neither heroines nor victims but rather share spaces in which they can carry out acts of resistance against a globally/locally situated oppressive power. In other words, we need to constantly compare our Western conceptual frameworks with the state of the conflict and the situations it gives rise to. To make these comparisons, we need to situate the conflict's genealogy (as we did earlier) and study the cultural ecology (which comprises both the campaign's physical 
and virtual elements). In this context, one should note that the Nigerian government went so far as to say that it suspected Boko Haram agents had infiltrated the political structure (Njoroge, 2016). This conflict has put the Nigerian Government's incompetence under the spotlight. It has also led to the country refusing international aid for fear of interventionist policies. Yet the same Chibok patriarchal conflict has also highlighted the need for 'glocal' [global/local] frameworks to help in such cases. Maybe we need to shift towards drawing up cyber-campaign strategies that focus on the different women found in NorthEastern Nigeria (whether they be political, literary, or media figures, or even members of the Boko Haram terrorist group). Such an approach would let us draw upon their life experiences rather than upon our Western pre-conceived notions.

The way the campaign was designed ensured that it had a big international impact but it also made it harder to resolve the conflict once it had gone viral, jumping from the local to the world scale. This is why contemporary feminism must exercise great caution to avoid such mistakes in future cyber-campaigns. Using celebrities/public figures (Michelle Obama, David Cameron) to promote voices, and using Westernstyle pictures on campaign posters has only helped Boko Haram turn the victims into bargaining chips. A relational approach would use ways of avoiding such individualisation, which manifests representationalist intersectionalities and that, in the final analysis, only fosters a de-localised social conflict that de-legitimises local agents.

\section{CONCLUSIONS}

Ezekwesili (2014, Minute 13) told us that structural solutions are needed when structural problems arise. Gender violence in war zones is a structural problem underlain by many socio-cultural layers. These layers cannot be simplified through the simple logic of causeand-effect. Here, social network campaigns can be agents of change as long as their strategies and design are approached from a gender perspective. Throughout this paper, we have eschewed generalist approaches and Western perspectives in order to understand a conflict that began five years ago. Sadly, that conflict is far from being a one off - similar ones break out today even though they may differ in form.

Women's bodies remain a bargaining chip for terrorist groups, political institutions, and even the media. Gender-based violence against women's and girls' bodies is a constant in our society, be it Western, Eastern, Northern or Southern. The contemporary media landscape offers a rising tide of cases as the scourge of right-wing extremist ideology reaches every corner of the world.

The path taken by the project and work done for this paper lead us to stress an idea proposed by Maxfield (2016: 889), namely that "Digital expressions were [and are] part of a broader reality underlying power systems and histories". Understanding a conflict therefore means placing it in its geographical, spatial, temporal, and power settings and linking these to the subjects involved at the outbreak of conflict. Cyber-campaigns offer excellent platforms for raising one's voice in protest but these voices should not drown out the stories of those directly affected. We must therefore take various elements into account, such as: individualisation in the campaign; media representation of the female body; categorisation of the people involved; the political strategy based on affirmation and not on negation or on the dual powers of post-colonial empowerment.

In addition, the campaign's path also reveals different ways of using social networks to tackle the problem of gender violence. The course of the \#BringBackOurGirls campaign and various geo-political events over the last five years have only muddied the waters, rendering the issues more complex. That is why when drawing up future anti-gender violence cyber-campaigns, we should think more about: which strategies to follow; how to make the leap from the local sphere to the global one; how to make the campaign go viral from the outset; reviewing the campaign's media treatment if the conflict drags on. 


\section{BIBLIOGRAPHIC REFERENCES}

Ajoke's Diary (September 17, 2014). Oby Ezekwesili Talks on \#BringBackOurGirls. [Video] https://www.youtube.com/ watch?v=cRTVEkBnoCk

Bonilla, Y. and Rosa, J. (2015). \#Ferguson: Digital Protest, Hashtag Ethnography, and the Racial Politics of Social Media in The United States. American Ethnologist. Journal of the American Ethnological Society, 42 (1), 4-16.

Braidotti, R. (2015). Posthuman Affirmative Politics. In S. Wilmer and A. Zukauskaité, (ed.), Resisting Biopolitics: Philosophical, Political and Performative Strategies (p. 30-56). London: Routledge.

Braidotti, R. (1990). Nomadic Subjects: Embodiment and Sexual Difference in Contemporary Feminist Theory. New York: Columbia University Press.

Official Twitter account of \#BringBackOurGirls [@BBOG_Nigeria] (n.d). Accessed $1^{\text {st }}$ September 2019 https://twitter. com/BBOG_Nigeria

Chiluwa, I. and Ifukor, P. (2015). 'War Against our Children': Stance and Evaluation in \#BringBackOurGirls Campaign Discourse on Twitter and Facebook. Discourse and Society, 26 (3), 267-296.

Cho, S., Crenshaw, K. and McCall, L. (2013). Toward a Field of Intersectionality Studies: Theory, Applications and Praxis. Signs: Journal of Women in Culture and Society, 38 (4), 785-810.

Coleman, R. (2018). Theorising the Present: Digital Media, Pre-emergence and Infra-structures of Feelings. Cultural Studies, 32 (4), 600-622.

Colman, F. (2020). Feminising Politics: Notes on Material and Temporal Feminist Modal Logics in Action. Matter: Journal of New Materialist Research, 1 (1), 1-22. DOI: 10.1344 / jnmr.v1i1.29895

Colman, F. (2014). Digital femininity: preaching and measurement, materialistic computing and images. Art Nodes: Magazine of Art, Science and Technology, 14, 7-17.

Channels Television (March 15, 2014a). Documentary: Oby Ezekwesili at the APC National Summit. Pt1. [Video] https:// www.youtube.com/watch? $=$ =PeMkCA-5nU

Channels Television (March 15, 2014b). Documentary: Oby Ezekwesili at the APC National Summit. Pt2. [Video] https:// www.youtube.com/watch?v=KUPBA6MZV2I

Geerts, E. and Van der Tuin, I. (2013). From Intersectionality to Interference: Feminist onto-Epistemological Reflections on the Politics of Representation. Women's Studies International Forum, 41 (3), 171-178. DOI: 10.1016 / j.wsif.2013.07.013

Haraway, D. (1988). Situated Knowledges (sic): The Science Question in Feminism and the Privilege of Partial Perspective. Feminist Studies, 14 (3), 575-599.

Harding, S. (1986). The Science Question in Feminism. Ithaca and London: Cornell University Press.

International Crisis Group (2016). Nigeria: Women and the Boko Haram Insurgency. Africa Report, 242. Retrieved from https://www.crisisgroup.org/file/4073/download?token=EDOh-MNR

Lazaar, M. (2007). Feminist Critical Discourse Analysis: Articulating a Feminist Discourse Praxis. Critical Discourse Studies, 4 (2), 141-146.

Mandrona, A. (2016). Ethical Practice and the Study of Girlhood. Girlhood Studies, 9 (3), 3-9.

Massumi, B. (2005). Fear (the spectrum said). Positions: East Asia Cultures Critique, 13 (1), 31-48.

Maxfield, M. (2016). History Re-tweeting Itself: Imperial Feminist Appropriations of "BringBackOurGirls". Feminist Media Studies, 16 (5), 886-900.

Mohanty, S. (1988). Under Western Eyes: Feminist Scholarship and Colonial Discourses. Feminist Review, 30 (1), $61-88$.

Njoroge, D. (2016). Global Activism or Media Spectacle? An Exploration of 'BringBackOurGirls' Campaign. In B. Mutsvairo (ed.), Digital Activism in the Social Media Era: Critical Reflections on Emerging Trends in Sub-Saharan Africa (p. 311-325). Switzerland: Pallgrave MacMillan.

Pink, S., Horst, H., Postill, J., Hjorth, L., Lewis, T. and Tacchi, J. (2016). Digital Ethnography: Principles and Practice. London: Sage Publications.

Revelles-Benavente, B. and González, A. (eds.) (2017) Teaching Gender: Feminist Pedagogies and Responsibilities in Times of Political Crisis. London and New York: Routledge.

Sassen, S. (2017). Interactions of the technical and the social. Digital formations of the powerful and the powerless. Debats. Revista de cultura, poder y sociedad, 131 (1), 163-181. 
Van der Tuin, I. (2015). Generational Feminism: A new Materialist Introduction to a Generative Approach. London: Lexington Books.

Whitty, M., Doodson, J., Creese, S. and Hodges, D. (2018). A Picture Tells a Thousand Words: What Facebook and Twitter Images Convey about our Personality. Personality and Individual Differences, 103, 109-114.

Xu, S. and Zhou, A. (2020). Hashtag Homophily in Twitter Network: Examining a Controversial Cause-related Marketing Campaign. Computers in Human Behavior, 102, 87-96.

\section{BIOGRAPHICAL NOTE}

Beatriz Revelles-Benavente is an Assistant Professor in the Department of English and German Languages at the University of Granada and a Professor for the Erasmus Mundus GEMMA Master: Women's Studies and Gender Literature at the University of Granada. She is co-editor of the scholarly journal Matter: Journal of New Materialist Research, and of the book Teaching Gender: Feminist Responsibilities and Pedagogies in Times of Political Crisis, published by Routledge (2017). 


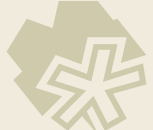

